\title{
TAHANAN GESEKAN SELIMUT PADA TIANG BOR PANJANG
}

\author{
Andrias Suhendra Nugraha \\ Jurusan Teknik Sipil, Universitas Kristen Maranatha \\ Jalan Prof. drg. Suria Sumantri, MPH., no.65 Bandung, 40164 \\ Email: andrias.sn@eng.maranatha.edu
}

\begin{abstract}
ABSTRAK
Penelitian ini bertujuan untuk mempelajari mekanisme transfer beban (load transfer) dan tahanan gesekan selimut (skin friction resistance) dari hasil uji beban aksial terinstrumentasi pada tiang bor (bored pile). Diameter tiang, d, yang ditinjau pada penelitian ini adalah $1.00 \mathrm{~m}$ dan panjang tiang, $\mathrm{L}$, yang ditinjau adalah $43.10 \mathrm{~m}$ dan $48.00 \mathrm{~m}$. Hasil uji beban aksial terinstrumentasi pada 2 tiang bor panjang (long bored pile) dengan ujung bawah tiang terletak pada tanah lanau (silt) dan lempung (clay) dengan konsistensi very stiff hingga hard menunjukkan bahwa tahanan gesekan selimut termobilisasi pada deformasi yang kecil yaitu pada $0.9 \% \mathrm{~d}$ hingga $2.6 \% \mathrm{~d}$.

Kata kunci : Tahanan gesekan selimut, Tiang bor, Uji beban aksial terinstrumentasi.
\end{abstract}

\section{ABSTRACT}

The objective of this research was to study of load transfer and skin friction resistance from axial loading tests of instrumented bored pile. Diameter of pile, $d$, which observed of this research is $1.00 \mathrm{~m}$ for both piles and length of pile, $L$, are $43.10 \mathrm{~m}$ and $48.00 \mathrm{~m}$. Axial loading tests of 2 instrumented long bored piles with pile tip at silt and clay with consistency very stiff to hard showed that skin friction resistance mobilized at small displacement, about $0.9 \% d$ to $2.6 \% d$.

Keywords : Skin friction resistance, Bored pile, Instrumented axially loading test.

\section{PENDAHULUAN}

Pondasi tiang bor adalah bagian struktur yang berfungsi menyalurkan beban dari struktur atas ke dalam tanah. Penyaluran beban kerja aksial dapat melalui tahanan dukung ujung (end bearing resistance) dan tahanan gesekan selimut (skin friction resistance).

Uji beban terinstrumentasi (instrumented loading test) pada tiang bor panjang yang dilakukan oleh Kruizinga dan Nelissen (1984) dan Balakrishnan (1994), menunjukkan bahwa persentase beban yang diterima oleh tahanan gesekan selimut jauh lebih besar (65\% sampai 90\% applied load) dibandingkan dengan beban yang diterima oleh tahanan dukung ujung. Hal ini dapat terjadi karena panjang tiang memungkinkan tahanan gesekan selimut termobilisasi pada deformasi yang jauh lebih kecil dari tahanan dukung ujung, sehingga tahanan gesekan selimut terjadi lebih dahulu sebelum beban dapat ditransfer ke tahanan dukung ujung (Woodward, 1972)

Pada penelitian ini, tinjauan pada tiang bor akan difokuskan pada mekanisme transfer beban dan tahanan gesekan selimut.

Tahanan Gesekan Selimut Pada Tiang Bor Panjang

(Andrias Suhendra Nugraha) 


\section{TUJUAN PENELITIAN}

Tujuan dari penelitian ini ialah untuk mengetahui dan mempelajari transfer beban dan tahanan gesekan selimut serta deformasi yang memobilisasinya, dari data hasil uji beban aksial terinstrumentasi pada tiang bor panjang

\section{KRITERIA PENGELOMPOKAN TIANG BOR}

Pondasi tiang bor merupakan salah satu jenis pondasi yang dikelompokan sebagai non-displacement pile. Kriteria pengelompokan tiang bor berdasarkan diameter (d), panjang (L), dan L/d, adalah sebagai berikut :

\section{- Kriteria diameter tiang (d)}

- Grigorian (1970) dan Pula (1975) : $\quad \mathrm{d}<0.6 \mathrm{~m} \quad$ tiang pendek

- Kriteria panjang tiang (L)

- Meyerhof (1976)

$$
: \mathrm{L}<20 \mathrm{~m} \quad \text { tiang pendek }
$$$$
\mathrm{L}>60 \mathrm{~m} \quad \text { tiang panjang }
$$

- Grigorian (1970) dan Pila (1975) : L $<5$ m tiang pendek

\section{- Kriteria L/d}

- Mates (1972) : $\quad \mathrm{L} / \mathrm{d}<25 \quad$ tiang pendek

- V.N.S. Murthy

$$
\text { L/d }>50 \quad \text { tiang panjang }
$$

- Grigorian (1970) dan Pula (1975): $\quad$ L/d $=2.5-8$ tiang pendek

\section{DAYA DUKUNG BATAS TIANG BOR}

Konsep dasar dari beban aksial yang ditahan oleh pondasi tiang tampak pada Gambar 1. Beban aksial batas, Qult dari tiang bor secara umum dapat dinyatakan sebagai berikut :

$$
\mathrm{Q}_{\mathrm{ult}}=\mathrm{Q}_{\mathrm{p}}+\mathrm{Q}_{\mathrm{s}}
$$

di mana :

$$
\begin{array}{ll}
\mathrm{Q}_{\mathrm{p}} & =\text { tahanan dukung ujung batas } \\
\mathrm{Q}_{\mathrm{s}} & =\text { tahanan gesekan selimut batas }
\end{array}
$$

$\mathrm{Q}_{\mathrm{s}}$ diperoleh dati integrasi $\tau_{\mathrm{a}}$ (pile-soil shear strength) disepanjang permukaan dari selimut tiang. $\tau_{\mathrm{a}}$ dapat dinyatakan sebagai berikut :

$$
\tau_{\mathrm{a}}=\mathrm{c}_{\mathrm{a}}+\sigma_{\mathrm{n}} \tan \phi_{\mathrm{a}}
$$

di mana : 


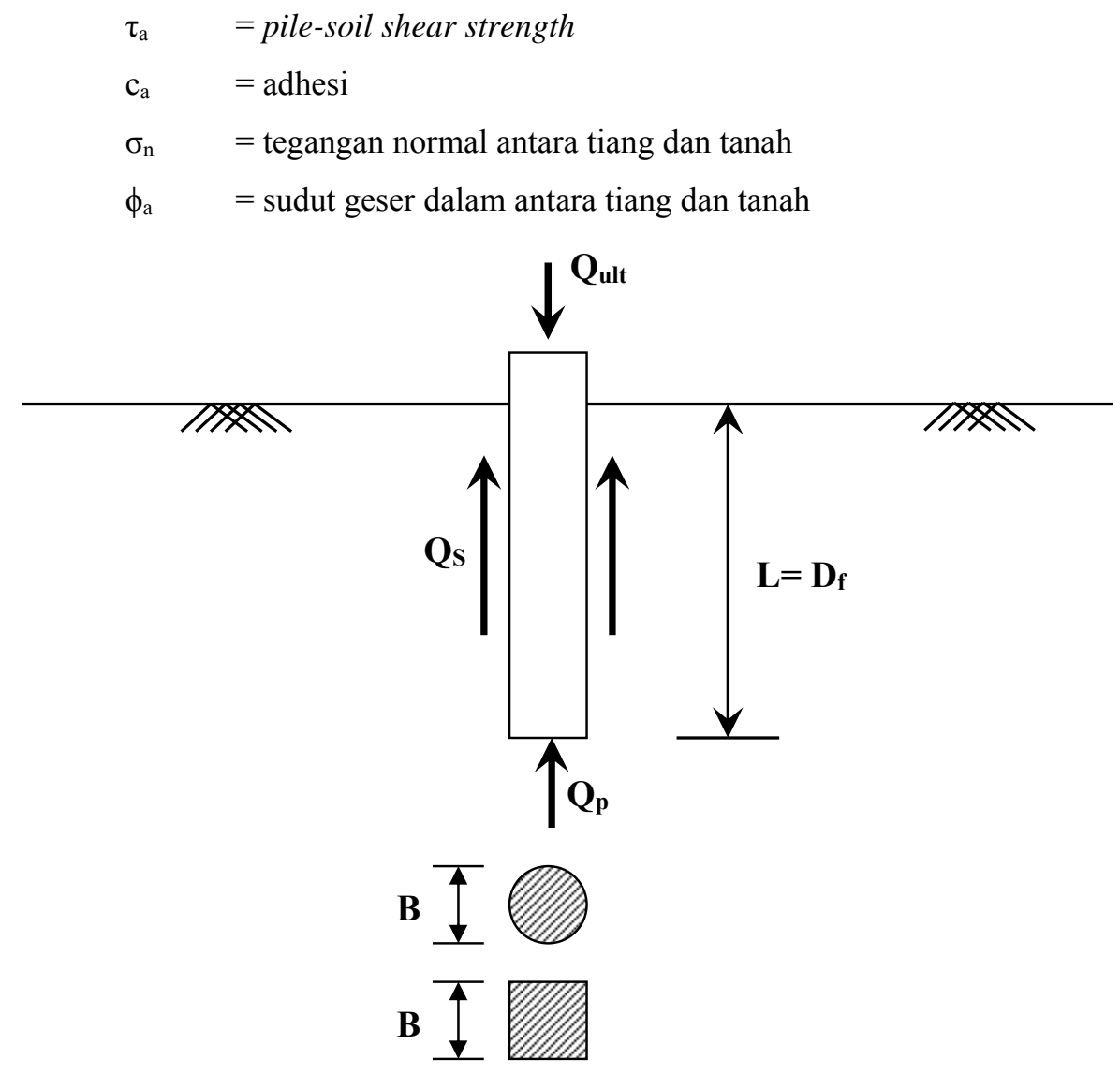

Gambar 1. Kurva transfer beban - deformasi

$\sigma_{\mathrm{n}}$ biasanya dinyatakan sebagai berikut :

$$
\sigma_{\mathrm{n}}=\mathrm{K}_{\mathrm{s}} \sigma_{\mathrm{v}}
$$

di mana :

$$
\begin{array}{ll}
\sigma_{\mathrm{n}} & =\text { tegangan vertical } \\
\mathrm{K}_{\mathrm{s}} & =\text { koefisien tekanan tanah lateral }
\end{array}
$$

sehingga,

$$
\tau_{\mathrm{a}}=\mathrm{c}_{\mathrm{a}}+\mathrm{K}_{\mathrm{s}} \sigma_{\mathrm{v}} \tan \phi_{\mathrm{a}}
$$

dan

$$
Q_{S}=\int_{0}^{L} C \tau_{a} d z=\int_{0}^{L} C\left(c_{a}+\sigma_{v} K_{S} \tan \phi_{a}\right) d z
$$

di mana :

$$
\begin{array}{ll}
\mathrm{C} & =\text { keliling tiang } \\
\mathrm{L} & =\text { panjang dari selimut tiang }
\end{array}
$$

Tahanan Gesekan Selimut Pada Tiang Bor Panjang (Andrias Suhendra Nugraha) 
Menurut teori daya dukung, tahanan dukung ujung, $\mathrm{Q}_{\mathrm{p}}$ dapat dinyatakan sebagai berikut :

$$
\mathrm{Q}_{\mathrm{p}}=\mathrm{A}_{\mathrm{b}}\left(\mathrm{c} \mathrm{N}_{\mathrm{c}}+\sigma_{\mathrm{vb}} \mathrm{N}_{\mathrm{q}}+0.5 \gamma \mathrm{d} \mathrm{N} \mathrm{N}_{\gamma}\right)
$$

di mana :

$$
\begin{array}{ll}
\mathrm{A}_{\mathrm{b}} & =\text { luas dari dasar tiang } \\
\mathrm{c} & =\text { kohesi tanah } \\
\sigma_{\mathrm{vb}} & =\text { tegangan vertikal pada tanah di dasar tiang } \\
\gamma & =\text { berat volume tanah } \\
\mathrm{d} & =\text { diameter tiang } \\
\mathrm{N}_{\mathrm{c}}, \mathrm{N}_{\mathrm{q}}, \mathrm{N}_{\gamma} & \text { = parameter daya dukung (tidak berdimensi) }
\end{array}
$$

Dari persamaan (1), (5), dan (6) diperoleh beban aksial batas tiang adalah sebagai berikut:

$$
Q_{S}=\int_{0}^{L} C\left(c_{a}+\sigma_{v} K_{S} \tan \phi_{a}\right) d z+A_{b}\left(c N_{C}+\sigma_{v b}+0.5 \gamma d N_{\gamma}\right)
$$

Selain dari perhitungan empiris, beban aksial batas tiang juga dapat diperoleh dari hasil uji beban aksial terinstrumentasi di lapangan. Pada uji beban aksial terinstrumentasi dapat dilakukan pengukuran transfer beban pada setiap kedalaman secara langsung dengan menggunakan strain instrument maupun tidak langsung dengan menggunakan load cell.

Interpretasi beban rata-rata (average load) Q dengan panjang segmen tiang $\square \mathrm{L}$, dari pengukuran defleksi $\mathrm{R}$, yang diperoleh dari 2 strain rods/telltales adalah sebagai berikut :

$$
Q=A E_{c} \frac{R_{1}-R_{2}}{\Delta L}
$$

$$
\begin{array}{lll}
\text { di mana : } & \text { A } & =\text { luas beton } \\
& \mathrm{E}_{\mathrm{c}} & =\text { modulus elastisitas beton }
\end{array}
$$

Beban, Q pada setiap kedalaman pemasangan strain gauges (Vibrating Wire Strain Gauge, VWSG) dihitung dengan menggunakan persamaan sebagai berikut :

$$
\mathrm{Q}=\text { average strain of the strain gauge } \mathrm{x}\left(\mathrm{E}_{\mathrm{c}} \mathrm{A}_{\mathrm{c}}+\mathrm{E}_{\mathrm{s}} \mathrm{A}_{\mathrm{s}}\right)
$$

$$
\begin{array}{lll}
\text { di mana : } & \mathrm{A}_{\mathrm{c}} & =\text { luas beton } \\
& \mathrm{E}_{\mathrm{c}} & =\text { modulus elastisitas beton } \\
\mathrm{A}_{\mathrm{s}} & =\text { luas tulangan baja } \\
& \mathrm{E}_{\mathrm{s}} & =\text { modulus elastisitas baja }
\end{array}
$$

Tahanan gesekan selimut rata-rata diantara dua segmen pada tiang diperoleh dari persamaan sebagai berikut : 


$$
f_{S}=\frac{\Delta Q}{\text { Keliling tiang } . \Delta L}
$$

di mana : $\quad f_{s}$

$$
\Delta \mathrm{Q}
$$

$=$ tahanan gesekan selimut rata-rata

$\Delta \mathrm{L}$

= perubahan beban

$=$ panjang segmen tiang

\section{UJI BEBAN AKSIAL TERINSTRUMENTASI}

Tiang uji yang ditinjau pada penelitian ini berjumlah 2 buah yaitu Tiang Uji 1 (TU1) dan Tiang Uji 2 (TU2). Lokasi uji beban aksial terinstrumentasi dari TU1 (Lokasi 1) dan TU2 (Lokasi 2) adalah di daerah Jakarta. Klasifikasi tanah untuk lokasi 1 dan lokasi 2 tampak pada Tabel 1 dan Tabel 2.

Tabel 1. Klasifikasi tanah untuk lokasi uji 1

\begin{tabular}{|c|c|}
\hline $\begin{array}{c}\text { Kedalaman } \\
(\mathrm{m})\end{array}$ & Klasifikasi Tanah \\
\hline $0.0-9.4$ & Debonded Zone \\
\hline $9.4-17.0$ & Firm clayey silt with fine sand / stiff clayey silt \\
\hline $17.0-36.0$ & $\begin{array}{c}\text { Stiff clayey silt / stiff to very stiff weakly cemented silt / } \\
\text { sand / clayey silt }\end{array}$ \\
\hline $36.0-42.0$ & Weakly cemented silty sand / Hard clayey silt \\
\hline
\end{tabular}

Tabel 2. Klasifikasi tanah untuk lokasi uji 2

\begin{tabular}{|c|c|}
\hline $\begin{array}{c}\text { Kedalaman } \\
(\mathrm{m})\end{array}$ & Klasifikasi Tanah \\
\hline $0.0-18.0$ & Debonded Zone \\
\hline $18.0-24.0$ & Medium stiff to stiff silty clay \\
\hline $24.0-30.0$ & Stiff silty clay / Hard clay \\
\hline $30.0-42.0$ & Hard clay / Dense silty clay with sand \\
\hline $42-47.5$ & Very stiff to Hard silty clay \\
\hline
\end{tabular}


Dimensi, beban kerja (working load), instrumentasi yang digunakan dan propertis dari tiang uji tampak pada Tabel 3 hingga Tabel 5.

Tabel 3. Dimensi dan Working Load dari Tiang Uji

\begin{tabular}{|c|c|c|c|c|c|}
\hline Lokasi & $\begin{array}{c}\text { Nomor } \\
\text { Tiang } \\
\text { Uji }\end{array}$ & $\begin{array}{c}\text { Diameter } \\
\text { Tiang } \\
(\mathrm{mm})\end{array}$ & $\begin{array}{c}\text { Panjang } \\
\text { Tiang } \\
(\mathrm{m})\end{array}$ & L/d & $\begin{array}{c}\text { Working } \\
\text { Load } \\
\text { (ton) }\end{array}$ \\
\hline 1 & TU1 & 1000 & 43.10 & 43.10 & 560 \\
\hline 2 & TU2 & 1000 & 48.00 & 48.00 & 500 \\
\hline
\end{tabular}

Tabel 4. Sistem pembebanan dan instrumentasi dari Tiang Uji

\begin{tabular}{|c|c|c|}
\hline Tiang Uji & Sistem Pembebanan & Instrumentasi \\
\hline TU1 & $\begin{array}{l}\text { Slow Maintenanced Loading } \\
\text { Test, menggunakan: } \\
\text { - Dongkrak hidrolik } \\
\text { - Kentledge } \\
\text { - } 4 \text { siklus pembebanan }\end{array}$ & $\begin{array}{ll}\text { - } & \text { VWSG } \\
\text { - } & \text { Tell-tales rod } \\
\text { - } & \text { Levelling } \\
& \text { survey }\end{array}$ \\
\hline TU2 & $\begin{array}{l}\text { Slow Maintenanced Loading } \\
\text { Test, menggunakan : } \\
\text { - Dongkrak hidrolik } \\
\text { - } \quad \text { Kentledge } \\
\text { - } 6 \text { siklus pembebanan }\end{array}$ & $\begin{array}{ll}\text { - } & \text { VWSG } \\
\text { - } & \text { Tell-tales rod }\end{array}$ \\
\hline
\end{tabular}

Tabel 5. Mutu beton, slump, umur beton saat loading, jenis alat bor dan metode pengecoran Tiang Uji

\begin{tabular}{|c|c|c|c|c|c|}
\hline Tiang Uji & $\begin{array}{c}\text { Mutu beton } \\
(\mathrm{MPa})\end{array}$ & $\begin{array}{c}\text { Slump } \\
(\mathrm{mm})\end{array}$ & $\begin{array}{c}\text { Umur beton } \\
\text { saat loading }\end{array}$ & $\begin{array}{c}\text { Jenis alat } \\
\text { bor }\end{array}$ & $\begin{array}{c}\text { Metode } \\
\text { pengecoran }\end{array}$ \\
\hline TU1 & 35 & $150-200$ & 21 hari & $\begin{array}{c}\text { Rotary } \\
\text { Auger }\end{array}$ & $\begin{array}{c}\text { Placed by } \\
\text { tremie }\end{array}$ \\
\hline TU2 & 35 & - & 75 hari & $\begin{array}{c}\text { Rotary } \\
\text { Auger }\end{array}$ & $\begin{array}{c}\text { Placed by } \\
\text { tremie }\end{array}$ \\
\hline
\end{tabular}

Skema pemasangan instrumentasi yang digunakan pada TU1 dan TU2 tampak pada Gambar 2 dan Gambar 3. 


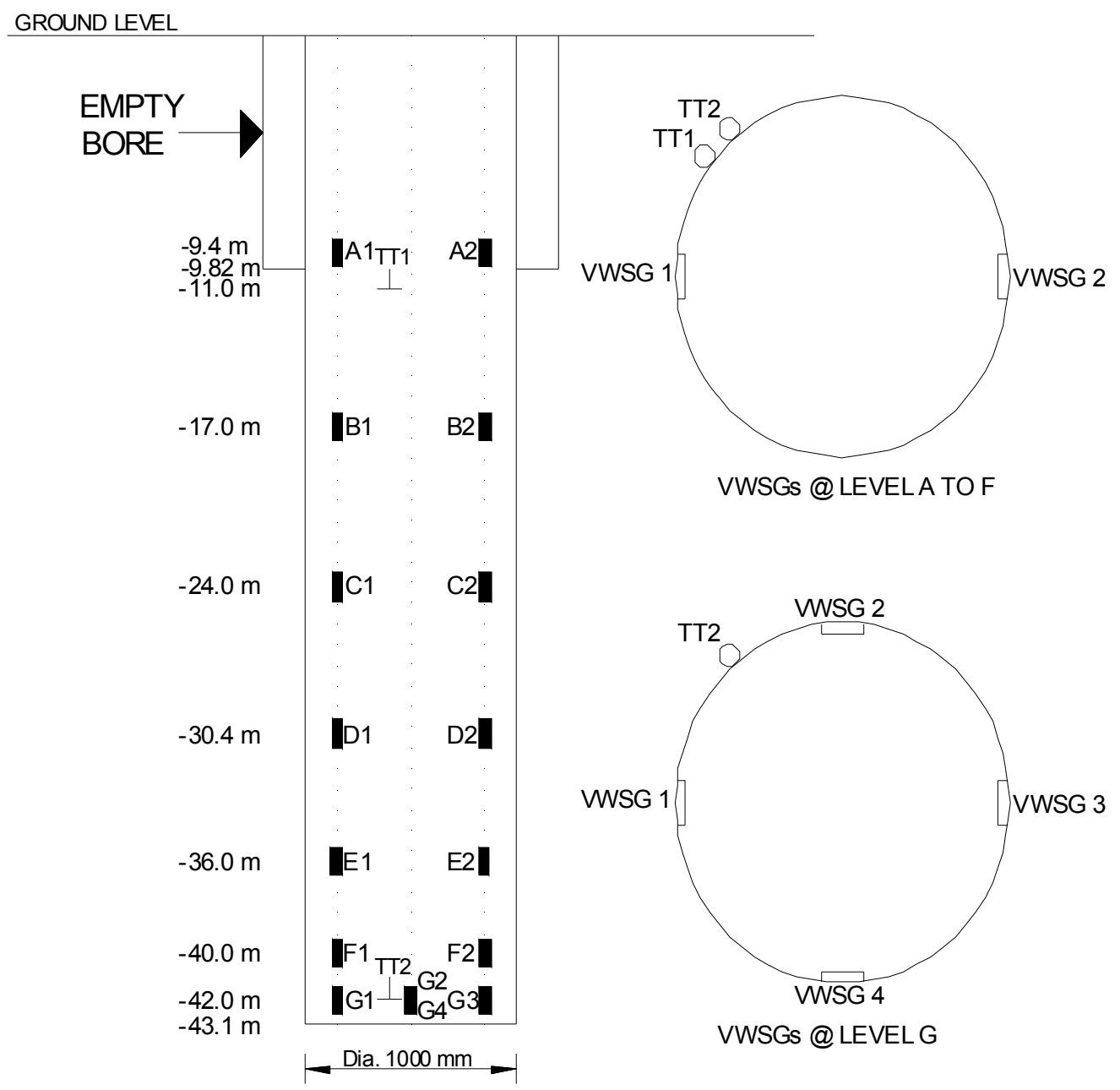

Gambar 2. Skema instrumentasi pada Tiang Uji 1 


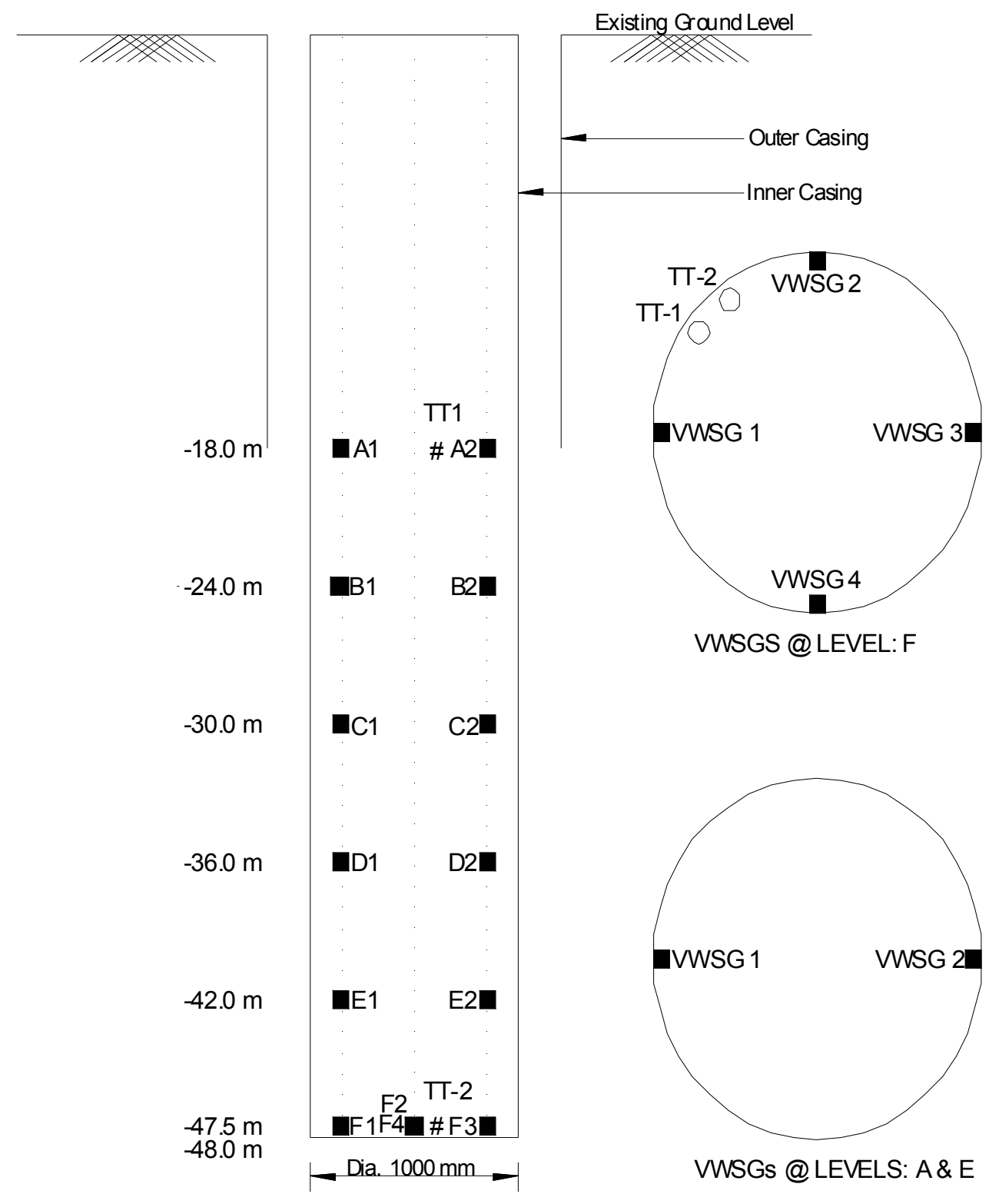

Gambar 3. Skema instrumentasi pada Tiang Uji 2

\section{HASIL UJI DAN PEMBAHASAN}

Tiang Uji 1 (TU1) dan Tiang Uji 2 (TU2) dapat diklasifikasikan sebagai tiang bor panjang (menurut Mates 1972, Murthy 1974, Grigorian 1970 dan Pula 1975). Tahanan gesekan selimut rata-rata termobilisasi (mobilised average unit skin friction) untuk setiap siklus pembebanan pada TU1 dan TU2 tampak pada Tabel 6 dan Tabel 7..

Tabel 6. Tahanan gesekan selimut rata-rata termobilisasi pada Tiang Uji 1 (TU1) 


\begin{tabular}{|c|c|c|c|c|}
\hline \multirow{2}{*}{$\begin{array}{l}\text { Kedalaman } \\
\quad(\mathrm{m})\end{array}$} & \multicolumn{4}{|c|}{$\begin{array}{l}\text { Tahanan gesekan selimut rata-rata termobilasi, } \mathrm{f}_{\mathrm{s}}\left(\mathrm{t} / \mathrm{m}^{2}\right) \\
\text { pada }\end{array}$} \\
\hline & $\begin{array}{c}0.5 \mathrm{xWL} \\
(280 \text { ton }) \\
1^{\text {st }} \text { cycle }\end{array}$ & $\begin{array}{c}1.0 \times \mathrm{xW} \\
(560 \text { ton) } \\
2^{\text {nd }} \text { cycle }\end{array}$ & $\begin{array}{c}1.5 \times W L \\
(840 \text { ton) } \\
3^{\text {rd }} \text { cycle }\end{array}$ & $\begin{array}{c}2.0 \times W L \\
(1120 \text { ton) } \\
4^{\text {th }} \text { cycle }\end{array}$ \\
\hline $0.0-9.4$ & \multicolumn{4}{|c|}{ Debonded Zone / Empty Bore } \\
\hline $9.4-17.0$ & 4.5 & 10.4 & 16.7 & 22.0 \\
\hline $17.0-36.0$ & 2.4 & 4.7 & 6.6 & $* 8.8$ \\
\hline $36.0-42.0$ & 0.1 & 0.7 & 1.7 & $* 2.7$ \\
\hline
\end{tabular}

*tidak termobilisasi secara penuh (not fully mobilized)

Tabel 7. Tahanan gesekan selimut rata-rata termobilisasi pada Tiang Uji 2 (TU2)

\begin{tabular}{|c|c|c|c|c|c|c|}
\hline \multirow{2}{*}{$\begin{array}{c}\text { Kedalaman } \\
(\mathrm{m})\end{array}$} & $\begin{array}{c}\text { Tahanan gesekan selimut rata-rata termobilasi, } \mathrm{f}_{\mathrm{s}}\left(\mathrm{t} / \mathrm{m}^{2}\right) \\
\text { pada }\end{array}$ \\
\cline { 2 - 7 } & $\begin{array}{c}0.44 \mathrm{xWL} \\
(218.8 \\
\text { ton) } \\
1^{\text {st }} \text { cycle }\end{array}$ & $\begin{array}{c}1.0 \mathrm{xWL} \\
(504.7 \\
\text { ton) } \\
2^{\text {nd }} \text { cycle }\end{array}$ & $\begin{array}{c}1.52 \times \mathrm{xL} \\
(760.6 \\
\text { ton) } \\
3^{\text {rd }} \text { cycle }\end{array}$ & $\begin{array}{c}1.99 \mathrm{xWL} \\
(995.9 \\
\text { ton }) \\
4^{\text {th }} \text { cycle }\end{array}$ & $\begin{array}{c}2.47 \mathrm{xWL} \\
(1233 \text { ton })\end{array}$ & $\begin{array}{c}2.99 \mathrm{xWL} \\
5^{\text {th }} \text { cycle } \\
(1493.1 \\
\text { ton) } \\
6^{\text {th }} \text { cycle }\end{array}$ \\
\hline $0.0-18.0$ & \multicolumn{7}{|c|}{ Debonded Zone } \\
\hline $18.0-24.0$ & 4.03 & 8.06 & 9.29 & 10.82 & 11.52 & 13.50 \\
\hline $24.0-30.0$ & 3.20 & 4.81 & 17.48 & 24.10 & 28.33 & 34.94 \\
\hline $30.0-42.0$ & 0.28 & 3.41 & 3.01 & 6.74 & 10.37 & 13.38 \\
\hline $42-47.5$ & 0.14 & 0.22 & 0.65 & 1.15 & 2.52 & 4.47 \\
\hline
\end{tabular}

Untuk Tiang Uji 1 (TU1), tahanan gesekan selimut rata-rata untuk setiap kedalaman VWSG saat kondisi pembebanan $1^{\text {st }}$ Cycle hingga $4^{\text {th }}$ Cycle tampak pada Tabel 8 hingga Tabel 11 dan kurva transfer beban saat kondisi pembebanan $1^{\text {st }}$ Cycle hingga $4^{\text {th }}$ Cycle tampak pada Gambar 4 hingga Gambar 7.

Untuk Tiang Uji 2 (TU2), tahanan gesekan selimut rata-rata untuk setiap kedalaman VWSG saat kondisi pembebanan $1^{\text {st }}$ Cycle hingga $6^{\text {th }}$ Cycle tampak pada Tabel 12 hingga Tabel 17 dan kurva transfer beban saat kondisi pembebanan $1^{\text {st }}$ Cycle hingga $6^{\text {th }}$ Cycle tampak pada Gambar 8 hingga Gambar 13.

Kurva transfer beban - deformasi dan kurva normalisasi transfer beban deformasi untuk TU1 dan TU2 tampak pada Gambar 14 hingga Gambar 17. 
Tabel 8. Tahanan gesekan selimut rata-rata untuk setiap kedalaman dari TU1 saat $1^{\text {st }}$ Cycle

\begin{tabular}{|c|c|c|c|}
\hline \multirow{4}{*}{ VWSG } & \multirow{4}{*}{ Kedalaman } & \multicolumn{2}{|c|}{ Tahanan Gesekan selimut rata-rata, $\mathrm{f}_{\mathrm{s}}\left(\mathrm{t} / \mathrm{m}^{2}\right)$} \\
\hline & & \multicolumn{2}{|c|}{$1^{\text {st }}$ Cycle } \\
\hline & & \multicolumn{2}{|c|}{ Beban } \\
\hline & & 140 ton & 280 ton \\
\hline & $0.0-9.4$ & \multicolumn{2}{|c|}{ Debonded Zone } \\
\hline A & 9.4 & 105.30 & 252.20 \\
\hline $\mathrm{B}$ & 17.0 & 58.50 & 145.60 \\
\hline $\mathrm{C}$ & 24.0 & 6.83 & 21.45 \\
\hline $\mathrm{D}$ & 30.4 & 3.90 & 10.40 \\
\hline $\mathrm{E}$ & 36.0 & 1.30 & 3.90 \\
\hline $\mathrm{F}$ & 40.0 & 1.30 & 2.60 \\
\hline G & 42.0 & 1.30 & 1.30 \\
\hline
\end{tabular}

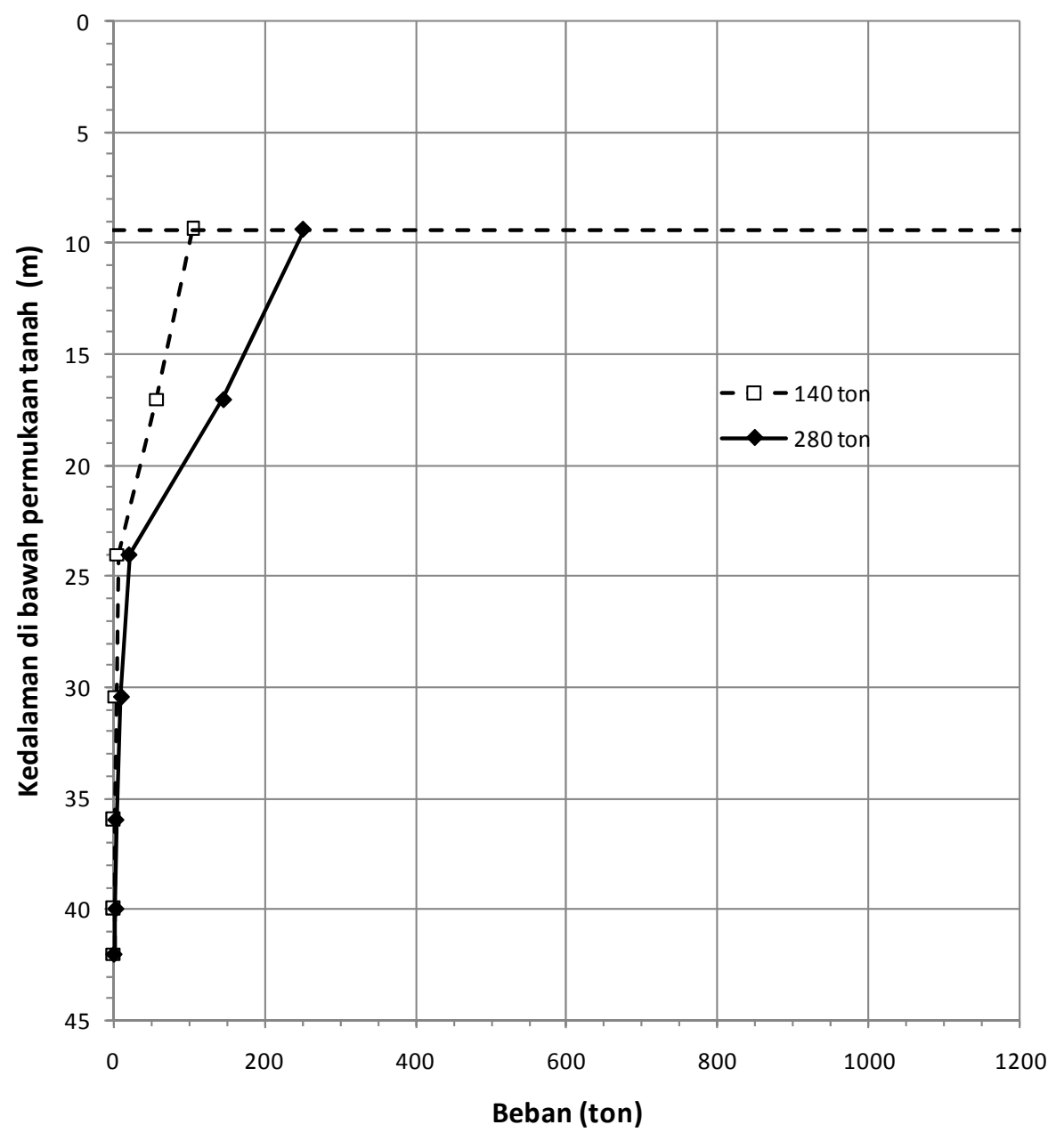

Gambar 4. Kurva transfer beban TU1 pada $1^{\text {st }}$ Cycle 
Tabel 9. Tahanan gesekan selimut rata-rata untuk setiap kedalaman dari TU1 saat $2^{\text {nd }}$ Cycle

\begin{tabular}{|c|c|c|c|c|}
\hline \multirow{5}{*}{ VWSG } & \multirow{4}{*}{$\begin{array}{l}\text { Kedalaman } \\
\text { (m) }\end{array}$} & \multicolumn{3}{|c|}{ Tahanan Gesekan selimut rata-rata, $\mathrm{f}_{\mathrm{s}}\left(\mathrm{t} / \mathrm{m}^{2}\right)$} \\
\hline & & \multicolumn{3}{|c|}{$2^{\text {nd }}$ Cycle } \\
\hline & & \multicolumn{3}{|c|}{ Beban } \\
\hline & & 280 ton & 420 ton & 560 ton \\
\hline & $0.0-9.4$ & \multicolumn{3}{|c|}{ Debonded Zone } \\
\hline $\mathrm{A}$ & 9.4 & 256.10 & 396.50 & 546.00 \\
\hline $\mathrm{B}$ & 17.0 & 146.90 & 224.90 & 297.70 \\
\hline $\mathrm{C}$ & 24.0 & 19.50 & 48.75 & 105.30 \\
\hline D & 30.4 & 10.40 & 20.80 & 40.30 \\
\hline $\mathrm{E}$ & 36.0 & 3.90 & 9.10 & 16.90 \\
\hline $\mathrm{F}$ & 40.0 & 2.60 & 5.20 & 7.80 \\
\hline G & 42.0 & 1.95 & 3.25 & 3.90 \\
\hline
\end{tabular}

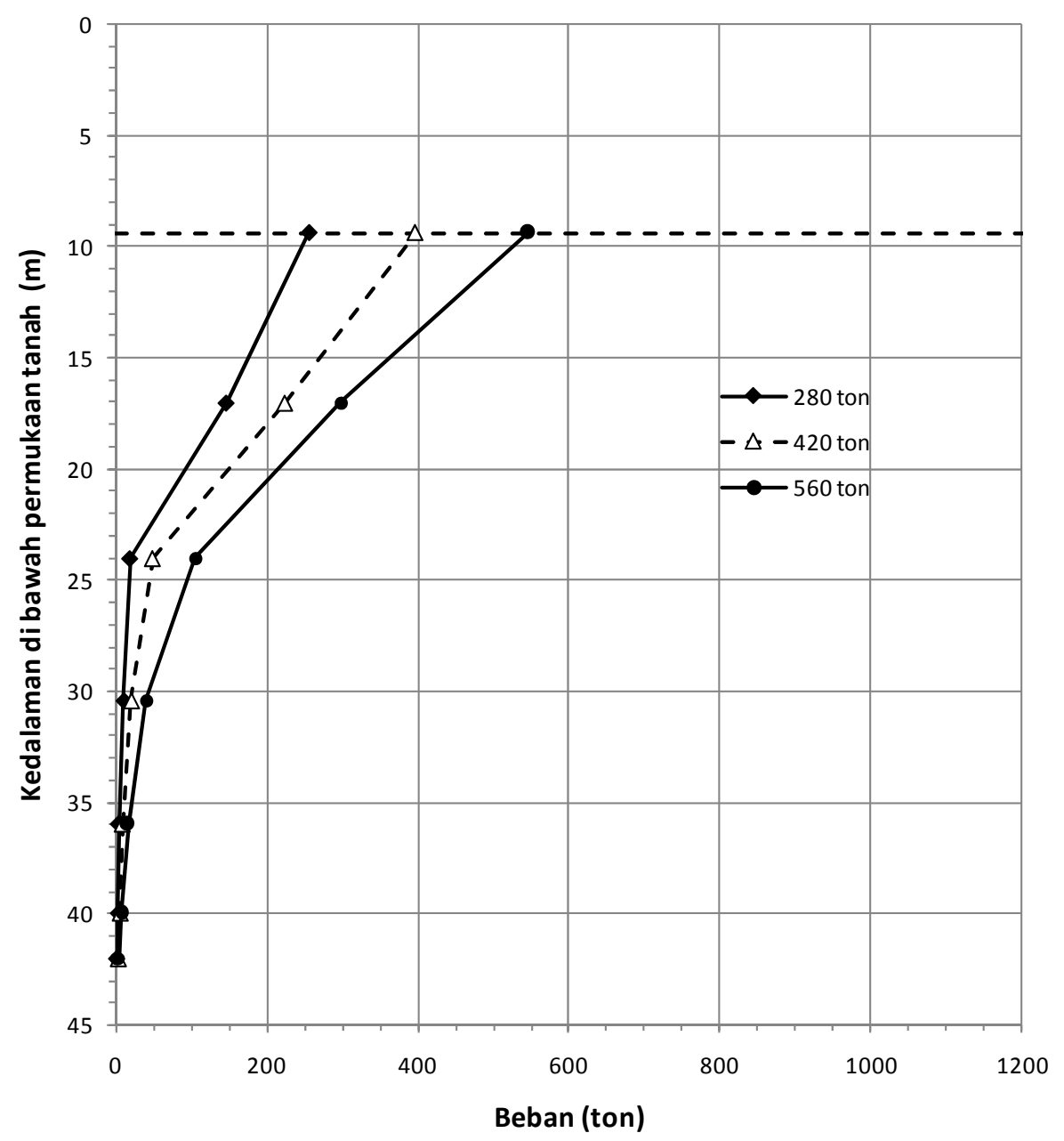

Gambar 5. Kurva transfer beban TU1 pada $2^{\text {nd }}$ Cycle 
Tabel 10. Tahanan gesekan selimut rata-rata untuk setiap kedalaman dari TU1 saat $3^{\text {rd }}$ Cycle

\begin{tabular}{|c|c|c|c|c|c|}
\hline \multirow{2}{*}{ VWSG } & \multirow{3}{*}{ Kedalaman } & \multicolumn{4}{|c|}{ Tahanan Gesekan selimut rata-rata, $\mathrm{f}_{\mathrm{s}}\left(\mathrm{t} / \mathrm{m}^{2}\right)$} \\
\cline { 3 - 6 } & & \multicolumn{4}{|c|}{$3^{\text {rd }}$ Cycle } \\
\cline { 3 - 6 } & & \multicolumn{4}{|c|}{ Beban } \\
\cline { 3 - 6 } & & \multicolumn{4}{|c|}{ Debonded Zone } \\
\cline { 3 - 6 } & $0.0-9.4$ & 280 ton & 560 ton & 700 ton & 840 ton \\
\hline & 9.4 & 270.40 & 556.40 & 692.90 & 833.20 \\
\hline A & 17.0 & 137.80 & 296.40 & 365.30 & 433.20 \\
\hline B & 24.0 & 72.15 & 113.10 & 177.45 & 244.73 \\
\hline C & 30.4 & 27.30 & 42.90 & 74.10 & 113.10 \\
\hline D & 36.0 & 9.10 & 16.90 & 27.30 & 40.30 \\
\hline E & 40.0 & 5.20 & 9.10 & 14.30 & 18.20 \\
\hline F & 42.0 & 2.60 & 3.90 & 5.85 & 8.45 \\
\hline G & & &
\end{tabular}

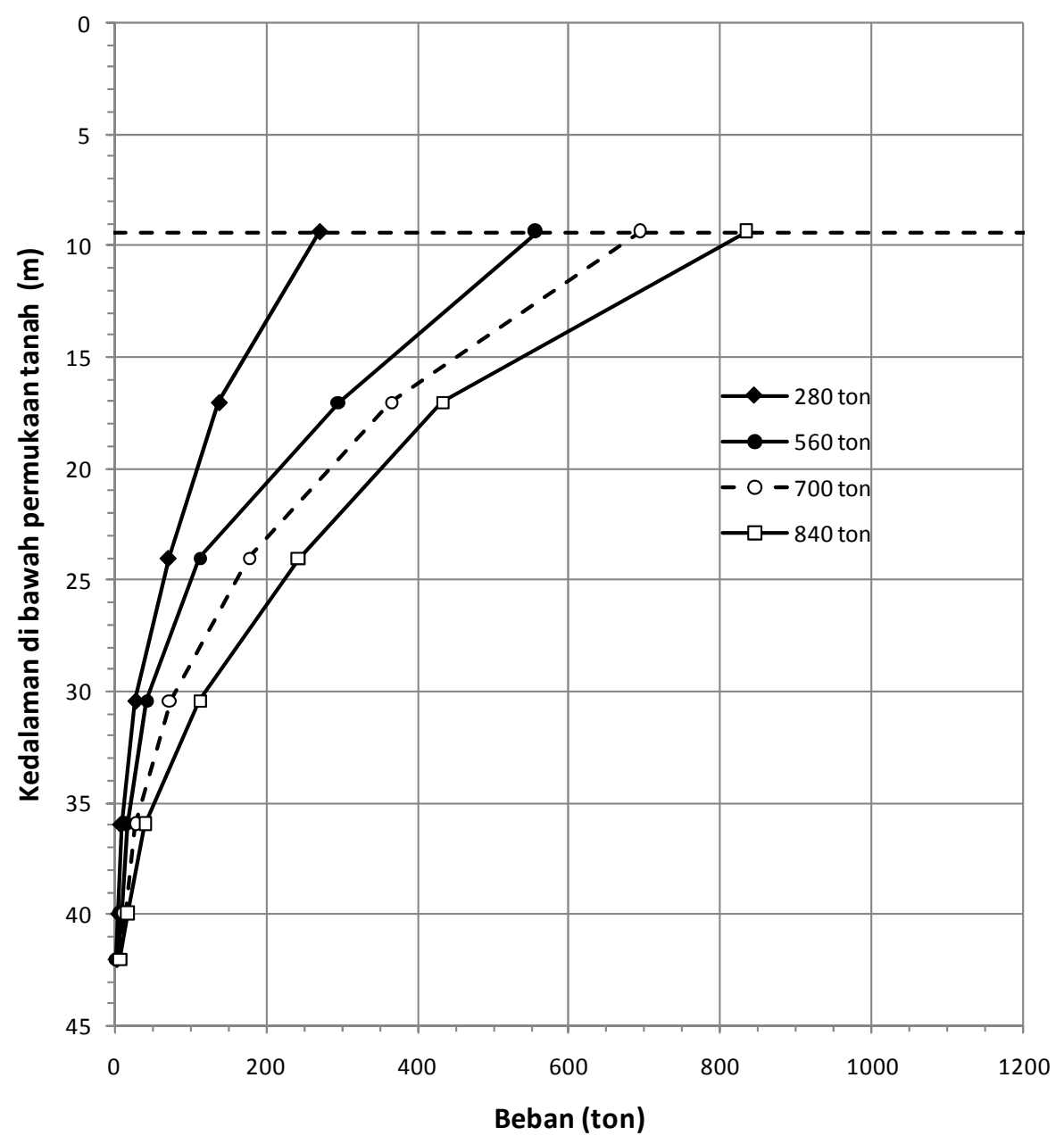

Gambar 6. Kurva transfer beban TU1 pada $3^{\text {rd }}$ Cycle 
Tabel 11. Tahanan gesekan selimut rata-rata untuk setiap kedalaman dari TU1 saat $4^{\text {th }}$ Cycle

\begin{tabular}{|c|c|c|c|c|c|c|}
\hline \multirow{4}{*}{ VWSG } & \multirow{4}{*}{ Kedalaman } & \multicolumn{5}{|c|}{ Tahanan Gesekan selimut rata-rata, $\mathrm{f}_{\mathrm{s}}\left(\mathrm{t} / \mathrm{m}^{2}\right)$} \\
\hline & & \multicolumn{5}{|c|}{$4^{\text {th }}$ Cycle } \\
\hline & & \multicolumn{5}{|c|}{ Beban } \\
\hline & & 280 ton & 560 ton & 840 ton & 980 ton & 1120 ton \\
\hline & $0.0-9.4$ & \multicolumn{5}{|c|}{ Debonded Zone } \\
\hline A & 9.4 & 296.40 & 564.20 & 826.80 & 956.80 & 1142.70 \\
\hline $\mathrm{B}$ & 17.0 & 156.00 & 275.60 & 425.10 & 495.30 & 596.70 \\
\hline $\mathrm{C}$ & 24.0 & 174.53 & 208.65 & 256.43 & 316.88 & 394.88 \\
\hline $\mathrm{D}$ & 30.4 & 84.50 & 98.80 & 122.20 & 161.20 & 210.60 \\
\hline $\mathrm{E}$ & 36.0 & 27.30 & 33.80 & 42.90 & 55.90 & 70.20 \\
\hline $\mathrm{F}$ & 40.0 & 13.00 & 16.90 & 19.50 & 26.00 & 35.10 \\
\hline G & 42.0 & 5.85 & 7.15 & 10.40 & 13.00 & 19.50 \\
\hline
\end{tabular}

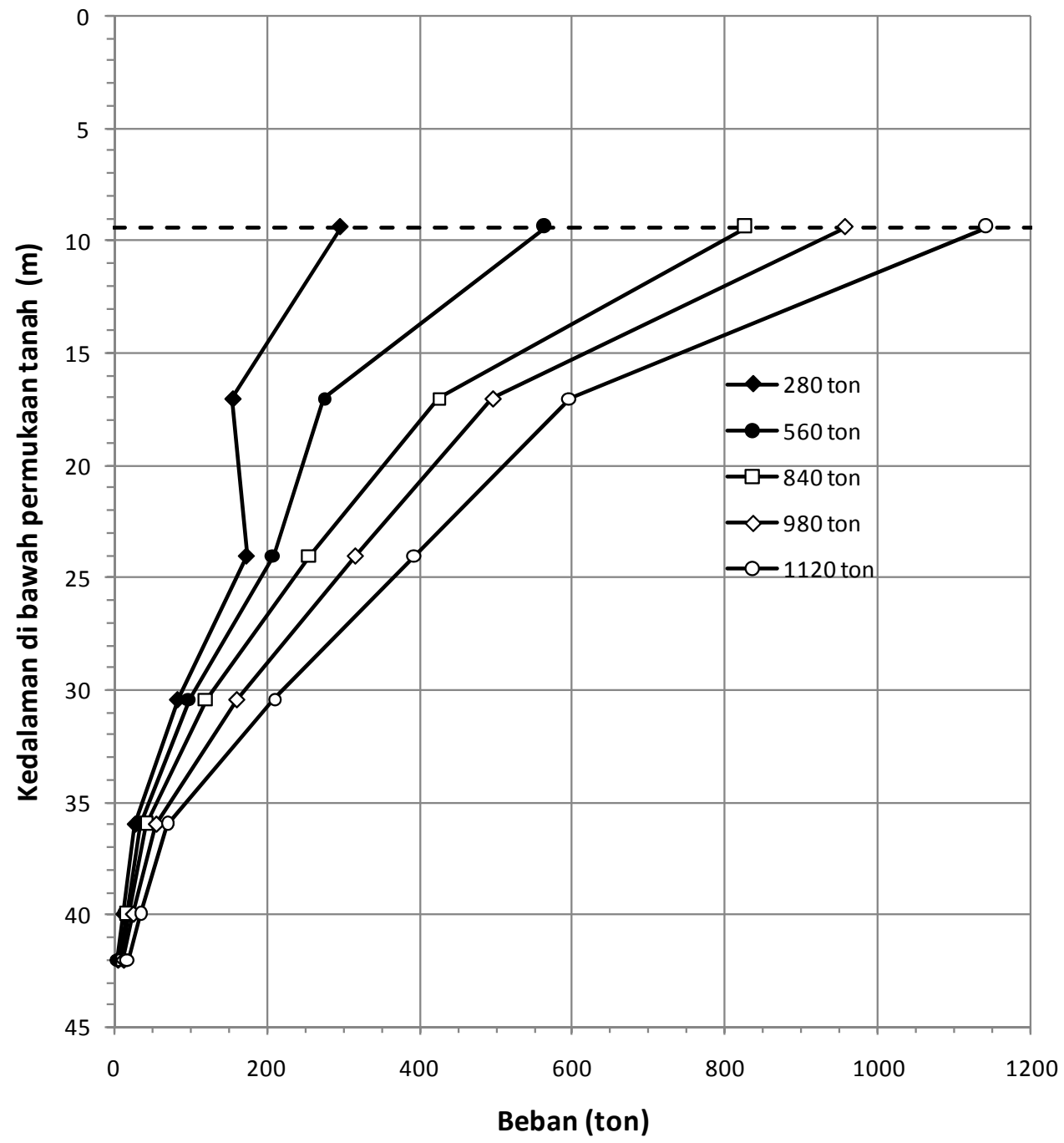

Gambar 7. Kurva transfer beban TU1 pada $4^{\text {th }}$ Cycle 
Tabel 12. Tahanan gesekan selimut rata-rata untuk setiap kedalaman dari TU2 saat $1^{\text {st }}$ Cycle

\begin{tabular}{|c|c|c|c|}
\hline \multirow{2}{*}{ WWSG } & \multirow{2}{*}{ Depth } & Tahanan Gesekan Selimut Rata-rata, $\mathrm{f}_{\mathrm{s}}\left(\mathrm{t} / \mathrm{m}^{2}\right)$ \\
\cline { 3 - 4 } & & \multicolumn{2}{|c|}{$1^{\text {st }}$ Cycle } \\
\cline { 3 - 4 } & & \multicolumn{2}{|c|}{ Beban } \\
\cline { 3 - 4 } & $(\mathrm{m})$ & 97.7 ton & 218.8 ton \\
\cline { 3 - 4 } & & \multicolumn{2}{|c|}{ Debonded Zone } \\
\hline & $18-18.0$ & 71.05 & 149.45 \\
\hline A & 24.0 & 33.62 & 73.46 \\
\hline B & 30.0 & 5.80 & 2.47 \\
\hline C & 36.0 & 2.49 & 0.00 \\
\hline D & 42.0 & 2.49 & 0.49 \\
\hline E & 47.5 & 0.62 & \\
\hline F & & \multicolumn{2}{|c|}{} \\
\hline
\end{tabular}

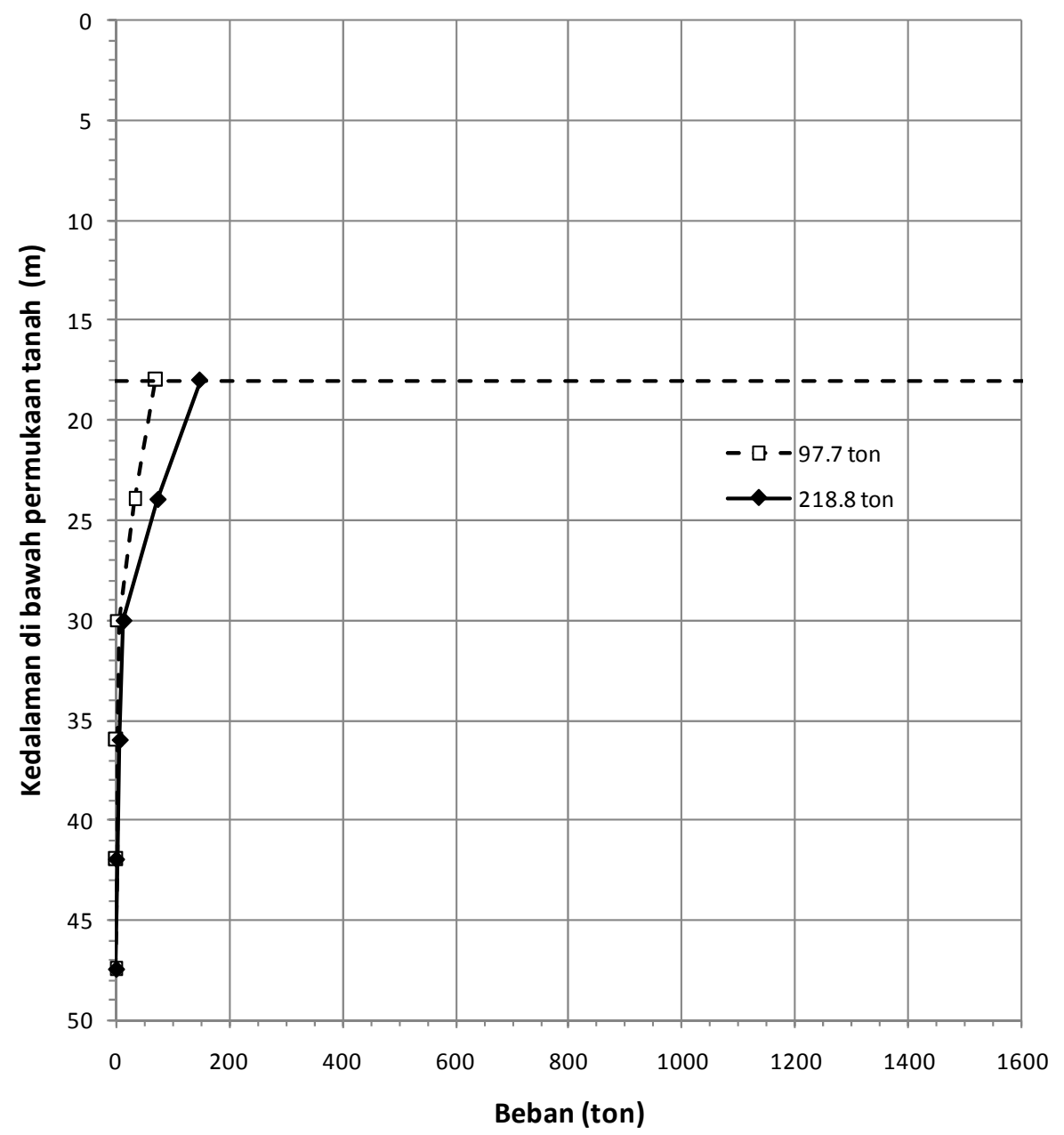

Gambar 8. Kurva transfer beban TU2 pada $1^{\text {st }}$ Cycle 
Tabel 13. Tahanan gesekan selimut rata-rata untuk setiap kedalaman dari TU2 saat $2^{\text {nd }}$ Cycle

\begin{tabular}{|c|c|c|c|c|}
\hline \multirow{2}{*}{ VWSG } & \multirow{3}{*}{ Depth } & \multicolumn{3}{|c|}{ Tahanan Gesekan Selimut Rata-rata, $\mathrm{f}_{\mathrm{s}}\left(\mathrm{t} / \mathrm{m}^{2}\right)$} \\
\cline { 3 - 5 } & & \multicolumn{3}{|c|}{$2^{\text {nd }}$ Cycle } \\
\cline { 3 - 5 } & & \multicolumn{3}{|c|}{ Beban } \\
\cline { 3 - 5 } & $(\mathrm{m})$ & 226 ton & 367.4 ton & 504.7 ton \\
\cline { 3 - 5 } & $0.0-18.0$ & 208.50 & 270.73 & 376.08 \\
\hline & 18.0 & 112.05 & 144.42 & 224.10 \\
\hline A & 24.0 & 75.40 & 95.70 & 133.40 \\
\hline B & 30.0 & 37.35 & 48.56 & 67.23 \\
\hline C & 36.0 & 2.49 & 2.49 & 1.25 \\
\hline D & 42.0 & 0.62 & 0.62 & \\
\hline E & 47.5 & & \\
\hline F & & &
\end{tabular}

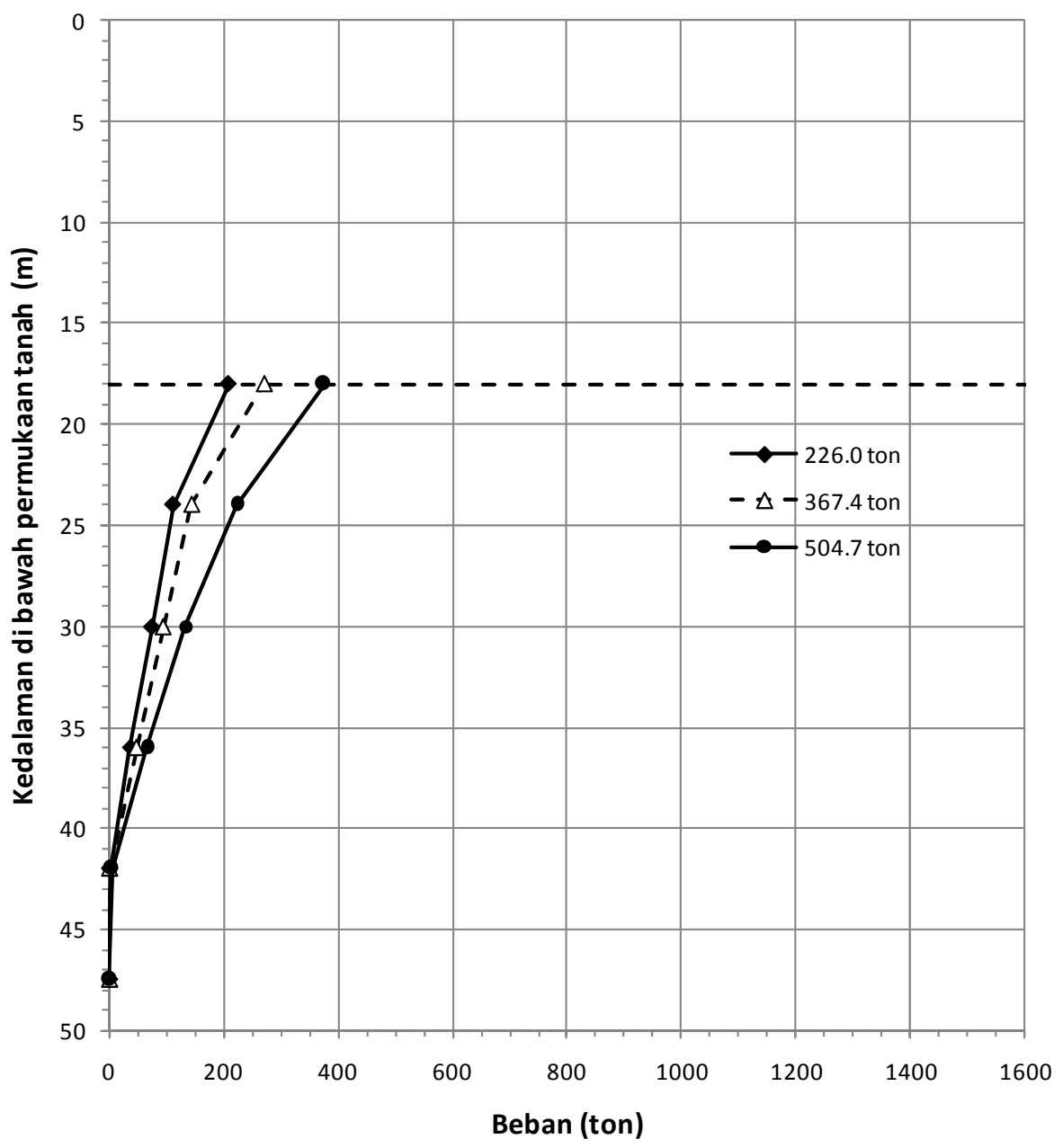

Gambar 9. Kurva transfer beban TU2 pada $2^{\text {nd }}$ Cycle 
Tabel 14. Tahanan gesekan selimut rata-rata untuk setiap kedalaman dari TU2 saat $3^{\text {rd }}$ Cycle

\begin{tabular}{|c|c|c|c|c|c|}
\hline \multirow{3}{*}{ VWSG } & \multirow{3}{*}{ Depth } & \multicolumn{4}{|c|}{ Tahanan Gesekan Selimut Rata-rata, $\mathrm{f}_{\mathrm{s}}\left(\mathrm{t} / \mathrm{m}^{2}\right)$} \\
\cline { 3 - 6 } & & \multicolumn{5}{|c|}{$3^{\text {rd }}$ Cycle } \\
\cline { 3 - 6 } & & \multicolumn{4}{|c|}{ Beban } \\
\cline { 3 - 6 } & & \multicolumn{4}{|c|}{ Debonded zone } \\
\cline { 3 - 6 } & & 243.9 ton & 386.4 ton & 610.3 ton & 760.6 ton \\
\hline & $0.0-18.0$ & 246.23 & 382.20 & 494.40 & 630.88 \\
\hline A & 18.0 & 151.89 & 230.33 & 318.72 & 455.67 \\
\hline B & 24.0 & 26.10 & 43.50 & 68.15 & 126.15 \\
\hline C & 30.0 & 12.45 & 22.41 & 37.35 & 77.19 \\
\hline D & 36.0 & 2.49 & 2.49 & 7.47 & 12.45 \\
\hline E & 42.0 & 1.25 & 0.00 & 1.25 & 1.25 \\
\hline F & 47.5 & & & \\
\hline
\end{tabular}

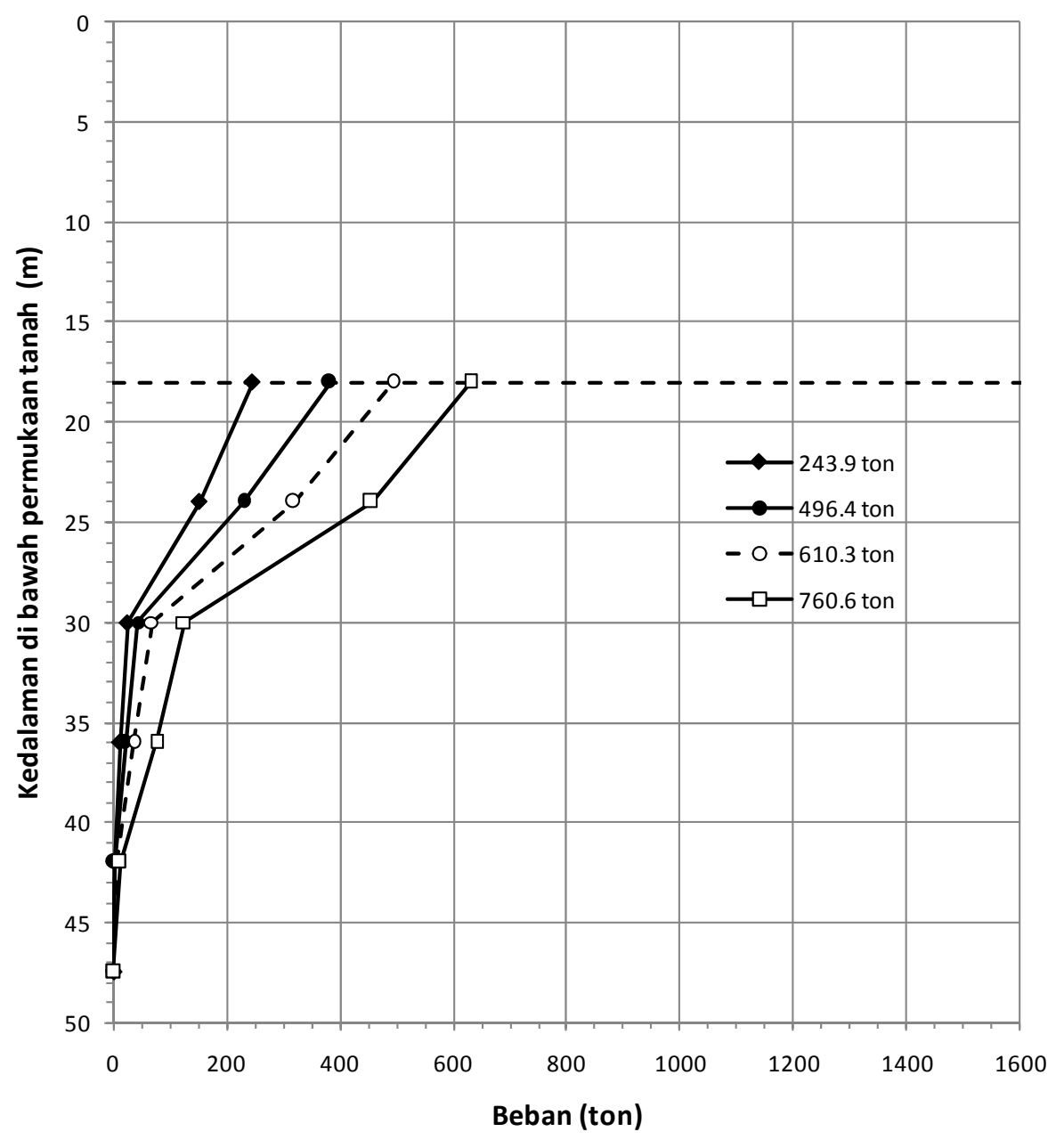

Gambar 10. Kurva transfer beban TU2 pada $3^{\text {rd }}$ Cycle 
Tabel 15. Tahanan gesekan selimut rata-rata untuk setiap kedalaman dari TU2 saat $4^{\text {th }}$ Cycle

\begin{tabular}{|c|c|c|c|c|c|c|}
\hline \multirow{3}{*}{ VWSG } & \multirow{3}{*}{ Depth } & \multicolumn{5}{|c|}{ Tahanan Gesekan Selimut Rata-rata, $\mathrm{f}_{\mathrm{s}}\left(\mathrm{t} / \mathrm{m}^{2}\right)$} \\
\cline { 3 - 7 } & & \multicolumn{5}{|c|}{$4^{\text {th }}$ Cycle } \\
\cline { 3 - 7 } & & \multicolumn{5}{|c|}{ Beban } \\
\cline { 3 - 7 } & & \multicolumn{5}{|c|}{ Debonded zone } \\
\cline { 3 - 7 } & & 259 ton & 499 ton & 756 ton & 860 ton & 995.9 ton \\
\hline & $0.0-18.0$ & 360.15 & 487.55 & 659.05 & 761.95 & 910.18 \\
\hline A & 18.0 & 339.89 & 380.97 & 470.08 & 573.95 & 698.45 \\
\hline B & 24.0 & 88.45 & 102.95 & 136.30 & 192.85 & 272.60 \\
\hline C & 30.0 & 49.80 & 62.25 & 82.17 & 124.50 & 186.75 \\
\hline D & 36.0 & 7.47 & 7.47 & 12.45 & 17.43 & 27.39 \\
\hline E & 42.0 & 0.62 & 0.62 & 1.25 & 1.87 & 1.25 \\
\hline F & 47.5 & & &
\end{tabular}

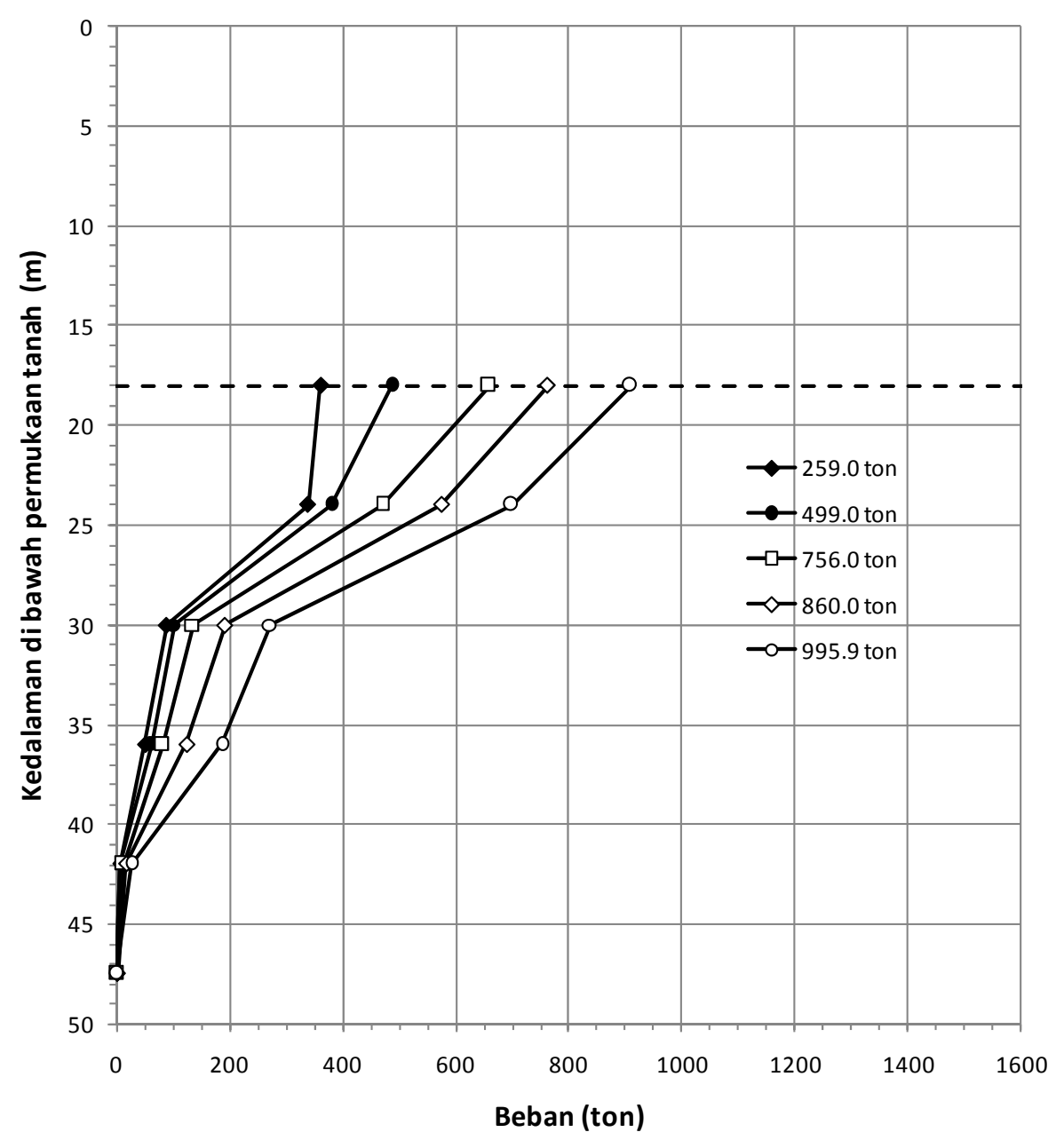

Gambar 11. Kurva transfer beban TU2 pada $4^{\text {th }}$ Cycle 
Tabel 16. Tahanan gesekan selimut rata-rata untuk setiap kedalaman dari TU2 saat $5^{\text {th }}$ Cycle

\begin{tabular}{|c|c|c|c|c|c|c|c|}
\hline \multirow{4}{*}{ VWSG } & \multirow{4}{*}{ Depth } & \multicolumn{6}{|c|}{ Tahanan Gesekan Selimut Rata-rata, $\mathrm{f}_{\mathrm{s}}\left(\mathrm{t} / \mathrm{m}^{2}\right)$} \\
\hline & & \multicolumn{6}{|c|}{$5^{\text {th }}$ Cycle } \\
\hline & & \multicolumn{6}{|c|}{ Beban } \\
\hline & & 246.8 ton & 509.7 ton & 744.7 ton & 995.9 ton & 1108.0 ton & 1233.0 ton \\
\hline & $0.0-18.0$ & \multicolumn{6}{|c|}{ Debonded zone } \\
\hline $\mathrm{A}$ & 18.0 & 450.80 & 665.18 & 752.15 & 943.25 & 1138.03 & 1191.93 \\
\hline $\mathrm{B}$ & 24.0 & 499.25 & 572.70 & 643.67 & 754.47 & 937.49 & 974.84 \\
\hline $\mathrm{C}$ & 30.0 & 200.10 & 221.85 & 250.85 & 298.70 & 420.50 & 440.80 \\
\hline $\mathrm{D}$ & 36.0 & 154.38 & 166.83 & 186.75 & 209.16 & 313.74 & 326.19 \\
\hline $\mathrm{E}$ & 42.0 & 14.94 & 17.43 & 24.90 & 27.39 & 47.31 & 49.80 \\
\hline $\mathrm{F}$ & 47.5 & 0.00 & 0.00 & 0.00 & 0.00 & 1.25 & 6.23 \\
\hline
\end{tabular}

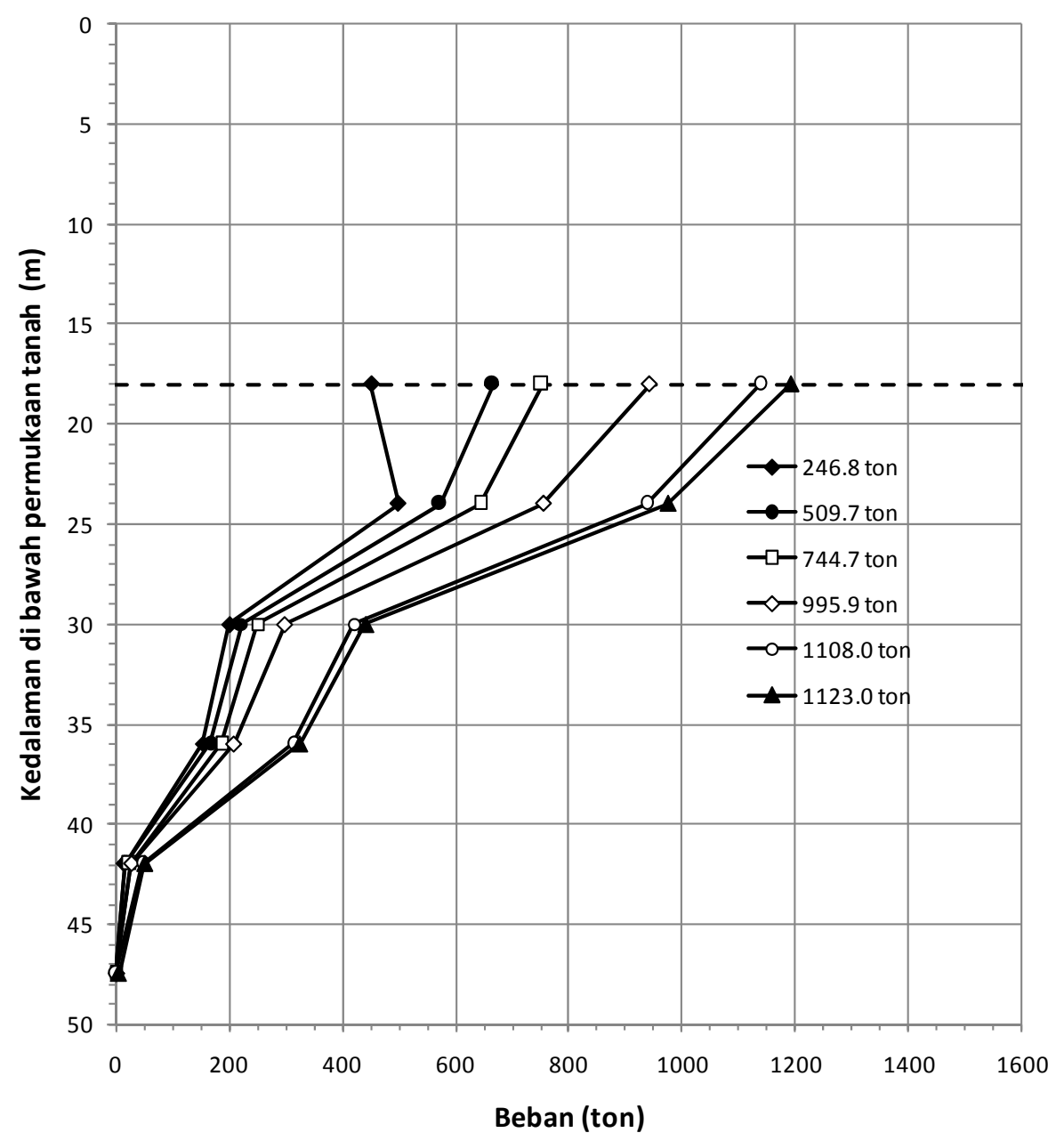

Gambar 12. Kurva transfer beban TU2 pada $5^{\text {th }}$ Cycle 
Tabel 17. Tahanan gesekan selimut rata-rata untuk setiap kedalaman dari TU2 saat $6^{\text {th }}$ Cycle

\begin{tabular}{|c|c|c|c|c|c|}
\hline \multirow{4}{*}{ VWSG } & \multirow{4}{*}{ Depth } & \multicolumn{4}{|c|}{ Tahanan Gesekan Selimut Rata-rata, $\mathrm{f}_{\mathrm{s}}\left(\mathrm{t} / \mathrm{m}^{2}\right)$} \\
\hline & & \multicolumn{4}{|c|}{$6^{\text {th }}$ Cycle } \\
\hline & & \multicolumn{4}{|c|}{ Beban } \\
\hline & & 241.0 ton & 506.0 ton & 1382.0 ton & 1493.1 ton \\
\hline & $0.0-18.0$ & \multicolumn{4}{|c|}{ Debonded Zone } \\
\hline A & 18.0 & 505.93 & 650.48 & 1424.68 & 1494.50 \\
\hline B & 24.0 & 641.18 & 709.65 & 1119.26 & 1240.02 \\
\hline$c$ & 30.0 & 313.20 & 334.95 & 516.20 & 581.45 \\
\hline $\mathrm{D}$ & 36.0 & 271.41 & 281.37 & 375.99 & 385.95 \\
\hline $\mathrm{E}$ & 42.0 & 37.35 & 42.33 & 72.21 & 77.19 \\
\hline $\mathrm{F}$ & 47.5 & 0.00 & 0.00 & 4.36 & 0.00 \\
\hline
\end{tabular}

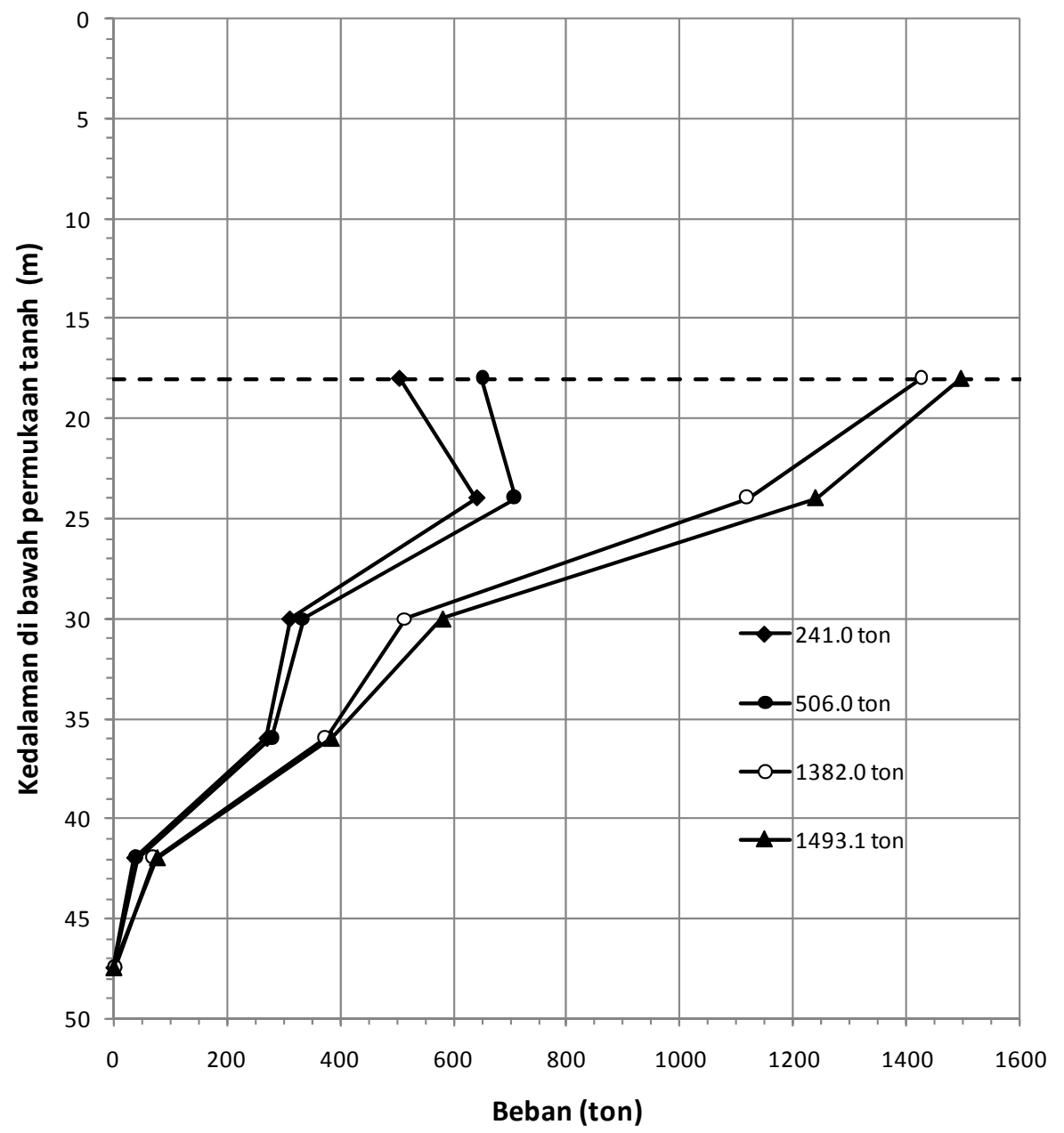

Gambar 13. Kurva transfer beban TU2 pada $6^{\text {th }}$ Cycle 


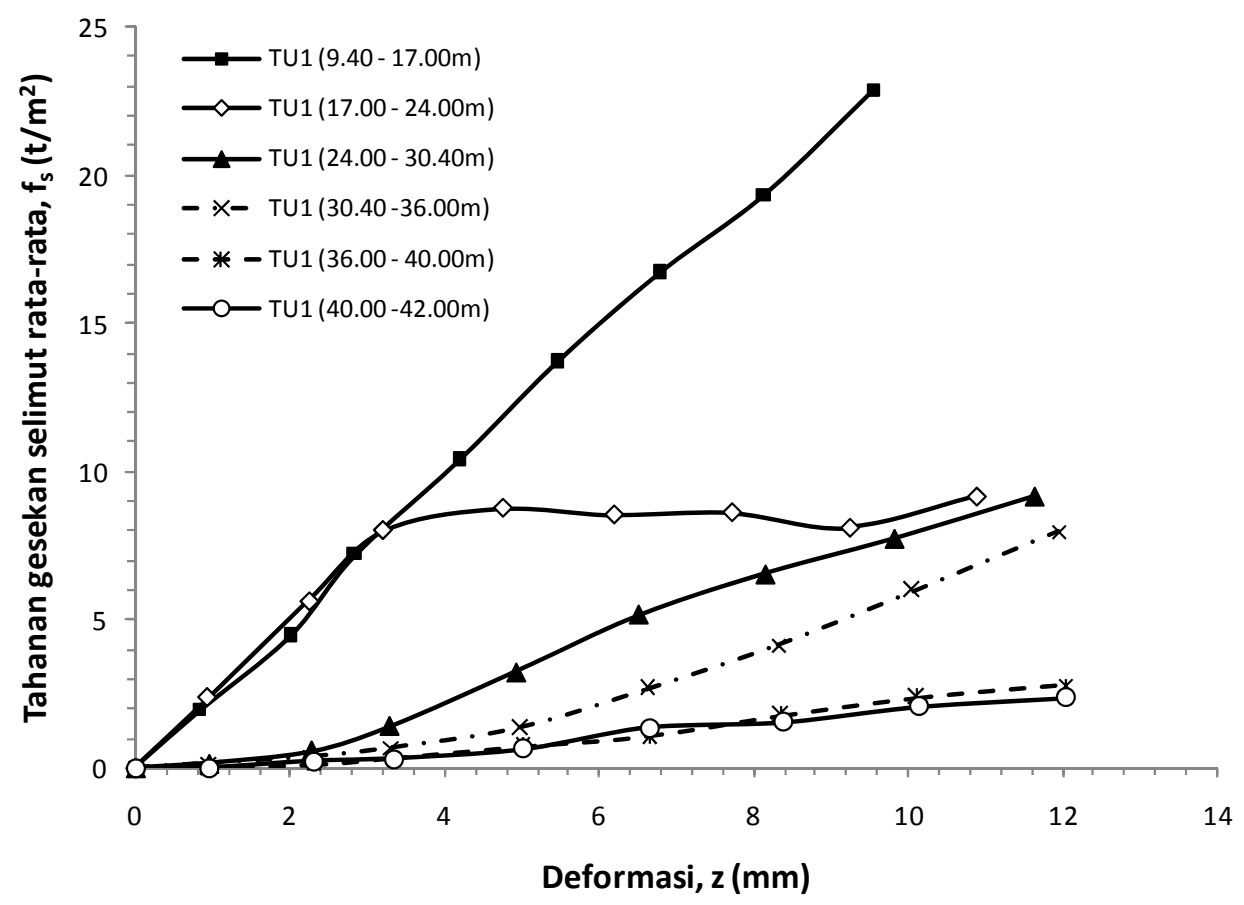

Gambar 14. Kurva transfer beban - deformasi untuk TU1

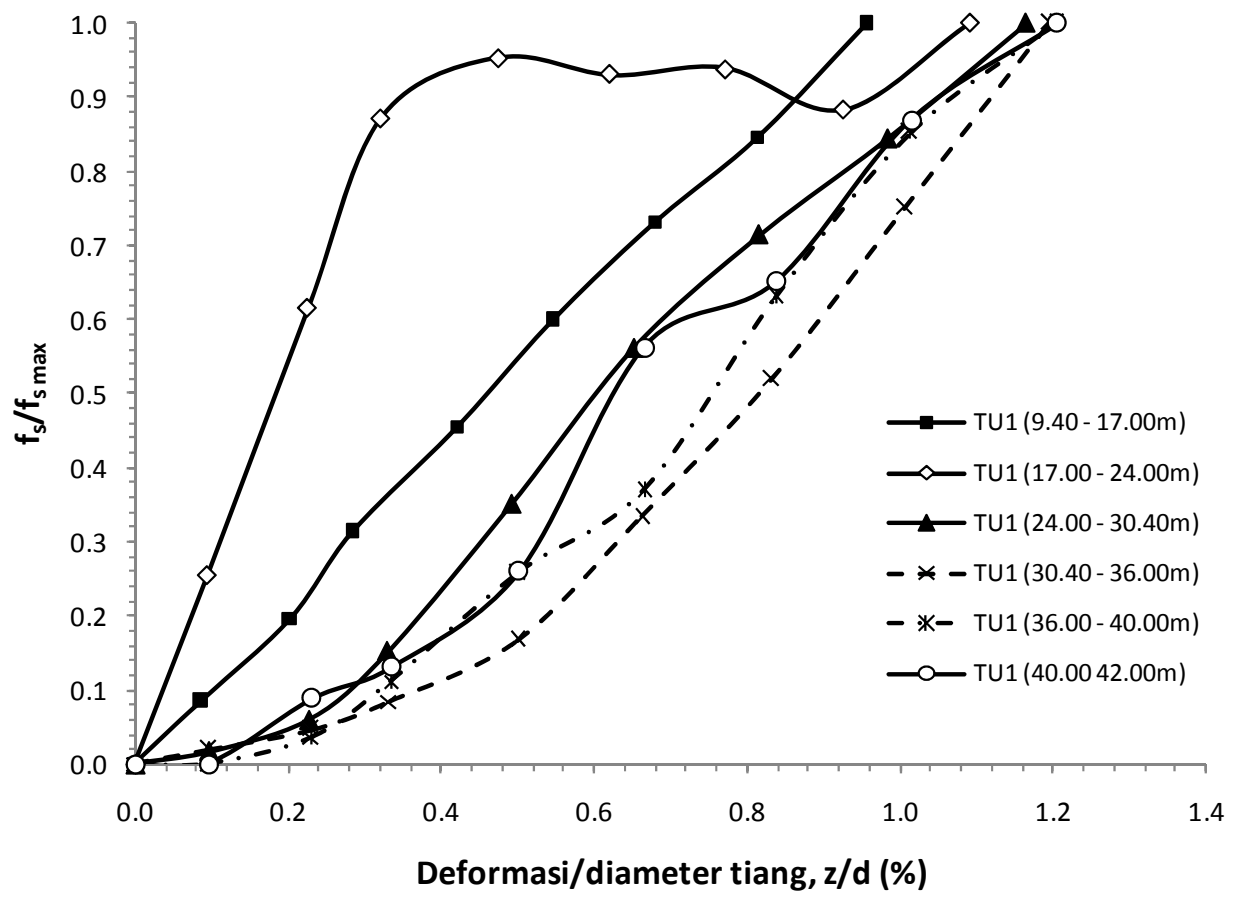

Gambar 15. Kurva normalisasi transfer beban - deformasi untuk TU1. 


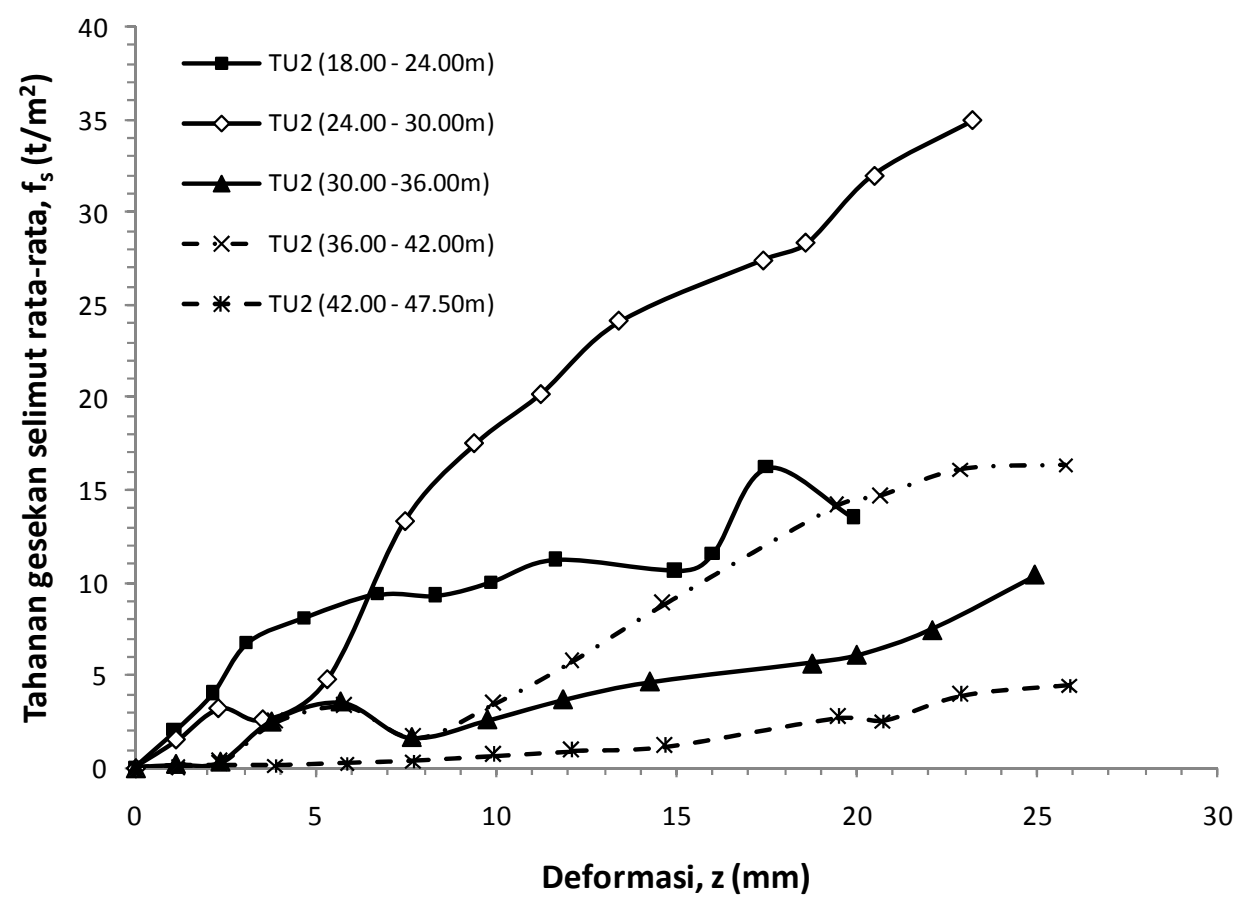

Gambar 16. Kurva transfer beban - deformasi untuk TU2

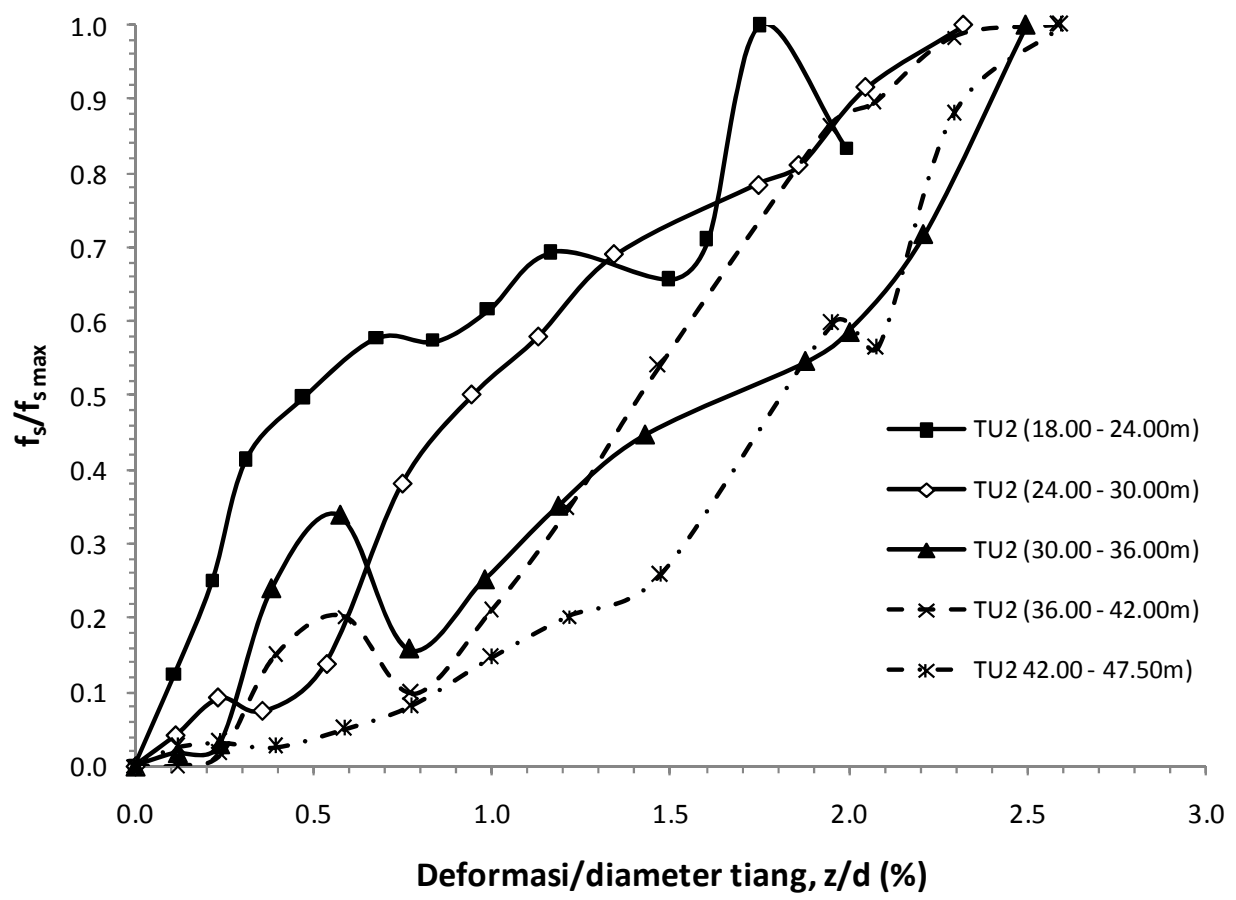

Gambar 17. Kurva normalisasi transfer beban - deformasi untuk TU2 


\section{SIMPULAN}

Simpulan dari penelitian ini antara lain adalah :

1. Tiang Uji 1 dan Tiang Uji 2 diklasifikasikan sebagai tiang bor panjang.

2. Kurva transfer beban pada Tiang Uji 1 dan Tiang Uji 2 menunjukan bahwa tahanan dukung ujung tidak termobilisasi.

3. Tahanan gesekan selimut termobilisasi pada deformasi $0.9 \% \mathrm{~d}$ hingga $2.6 \% \mathrm{~d}$ untuk kedua Tiang Uji (TU1 dan TU2).

\section{UCAPAN TERIMA KASIH}

Penulis mengucapkan terima kasih kepada Ir. Irawan Firmansyah, MSCE, yang telah memberikan data-data bagi penelitian ini.

\section{DAFTAR PUSTAKA}

1. Balakrishnan, E.G., (February, 1999, p.122-131). Load Deformation Analysis of Bored Piles in Residual Weathered Formation, Journal of Geotechnical and Geoenviromental Engineering.

2. Hunt, R.E., (1984). Geotechnical Engineering Investigation Manual, Mc GrawHill, New York.

3. Kruizinga, J., (1984, p.1417-1420). Behaviour of Bored and Auger Piles in Normally Consolidated Soils, International Conference on Soils Mechanics and Foundation Engineering.

4. Ng, W.W.C., (June, 2000, p.488-498). New Failure Criterion for Large Diameter Bored Pile in Weathered Geomaterials, Journal of Geotechnical and Geoenviromental Engineering.

5. Phienwej, N., (1995, p.251-260). Performance of Bored Piles in Weathered Meta-Sedimentary Rocks in Kuala Lumpur, Malaysia, Developments in Deep Foundations and Ground Improvement Scheme.

6. Poulos, H.G., Davis, E.H., (1980). Pile Foundation Analysis and Design, John Wiley \& Sons, Canada.

7. Prakash, S., Sharma, H.D., (1990). Pile Foundation in Engineering Practice, John Wiley \& Sons.

8. Terzaghi, K., Peck, R.B., Mesri, G., (1996). Soil Mechanics in Engineering Practice, John Wiley \& Sons. 
9. Woo, S.M., (1995, p. 69-85). Analysis of Pile Test Results, Development in Deep Foundations and Ground Improvement Schemes.

10. Woodward, Gardner, Greer, (1972). Drilled Pier Foundations, The Mc-GrawHill Companies, New York. 